\title{
A Dalit and a First Nations Canadian speak of the women in their bones
}

\author{
Maria Preethi Srinivasan
}

\author{
A nation is not conquered \\ Until the hearts of its women \\ Are on the ground \\ Then it is done, no matter \\ How brave its warriors \\ Nor how strong its weapons
}

Traditional Cheyenne saying ${ }^{1}$

My engagement with research on indigenous women's life writings with specific reference to the issue of 'gaining a voice', left me wondering about the singularity of 'voices' and the multiplicity of voices in 'a voice'. Bama's Sangati and Lee Maracle's I am woman presented themselves to me as texts that have many interesting points of intersection in their respective presentations about Indian Dalit women and First Nations women in Canada. Both Bama and Maracle seek to foreground through their narratives the 'difference' of the women of their respective communities from women of mainstream society and the irrelevance of mainstream feminist ideology in understanding the experiences of Dalit or Native women. It struck me as something amazing that two women writers from two geographical extremities should exhibit a similar approach to exploring and expressing issues that concern themselves and the group they represent. Another striking similarity was seen in their development as writers: each of them began their literary careers with the writing of their life stories/autobiographies and they moved on to narrating the lives of the women of their respective communities. Bama's autobiography Karukku was followed by the publication of Sangati; Maracle's I am woman followed the writing of Bobbi Lee: Indian rebel. ${ }^{2}$ Sangati is committed to the purpose of exposing the ramifications of caste hegemony in the lives of Dalit women. Her preoccupation with caste and gender is complemented by Maracle's commitment (in I am woman) to explicating the connection between racism and sexism.

\section{The road to Bama's Sangati}

Karukku was published in Tamil in 1992, a significant period in the history of Dalit struggles. 1992 was a year of Dalit awakening with the Ambedkar centenary celebrations. It was Father Mark Stephen a Catholic priest who seized this moment to present Bama's story. My pursuit of 'how' Bama 'gained a voice' engaged me in interviews with the publisher of the English version, Mini Krishnan of 
Macmillan and her translator, Lakshmi Holmstrom. A strong suggestion that I should interview Fr. Mark Stephen presented itself in the 'Author's Preface' to Karukku, in which Bama writes,

Father Mark understood the nature and sources of this book, and urged me to write it. Not only did he encourage me to give thought to each separate topic, he supported me in the writing of it, he worked tirelessly to bring it out in the shape of a book. ${ }^{3}$

Fr. Mark Stephen said that I was the first person to interview him about Bama. From him I learnt the story of how Karukku came to be published. When Bama left her convent, after seven years of service to the Catholic church, she came directly to Madurai and met Fr. Mark Stephen who hails from her own village, Pudupatti. She shared with him her tragic story of disappointment with the church and the discrimination that she had to endure in the convent on the grounds of caste. At that time Fr. Mark Stephen (who is not a Dalit) was engaged in a battle to purge the church of caste conflicts and discrimination against Dalits. He was one of the pioneers of the Dalit Christian Movement which later came to be known as the Dalit Christian Liberation Movement. Against this backdrop and the Dalit awakening through the Ambedkar Centenary celebrations, he sent out a call to Dalits to participate in a life writing seminar. The objective was to record the experiences of Dalit Christians through their self-written life stories. There was no stipulation about the educational qualifications of the participants. The only requirement was their interest in writing. There was a good response to this. Just after this seminar was over, Bama arrived from the convent in Jammu. She approached Fr. Mark, as she had nowhere else to go. Fr. Mark was a close friend of her family. He had known her from the time she was a child. He asked her to write her story, suggesting each topic on which she might write. She wrote it in literary Tamil. He asked her to rewrite it in the dialect of her people. She did so. All the while, he did not disclose to her his desire to have it published. Describing that moment when he declared his intention to her, Fr. Mark Stephen says:

Then she said: 'No!' She got a shock. She said, 'I thought you asked me to write to give vent to my feelings. You want to degrade our community'. I said: 'No, its not a question of degrading'. We [Bama and Fr. Mark Stephen] are from different caste backgrounds. I am a non-Dalit. But I have been working all along for Dalits and Dalit literature. Somehow I convinced her. ${ }^{4}$

Karukku proved a success not only because of the experience it presented but also because of the language it employed. Following the success of Karukku, Bama worked on a suggestion from Fr. Mark. He says in the interview: 
Then I asked her to write about Dalit women whom she encountered in the village, ordinary women who are not educated, how they go to the field, how they are in oppressive situations, what is the thing that makes them live, and their struggle against the caste structure, their life in the family, their male dominated society. She was very interested in this and she wrote the second one, Sangati (1994). That also came out very well. I liked the second one better than the first [Karukku]. Till that time there was the view that all women have the same problem. But her writing showed that Dalit women have an entirely different problem compared to caste women. At the same time they enjoy a certain type of freedom which the caste women don't enjoy. That aspect she brought out very well. $^{5}$

Karukku and Sangati were born of such mentoring and had good reception due to their being published at a time when Dalit activism was upbeat. The English translations of Karukku and Sangati were published in 2000 and 2005 respectively.

\section{From Bobbi Lee: Indian rebel to I am woman}

The production and publishing history of Bobbi Lee has one point of intersection with Bama's Karukku, in that, like the Dalit movement in India, it is set against the backdrop of Native activism through the Liberation Support Movement (LSM) and Native Alliance for Red Power (NARP). Maracle's life story was recorded on a tape recorder as part of a life writing project by members of the LSM (a Marxist political group) to which she belonged. It was a part of their 'Life Histories from the Revolution Series'. Don Barrett and Rick Sterling transcribed and edited her words: 80 hours of tape and three inches of manuscript were reduced to a slim volume bearing the title, Bobbi Lee, Indian rebel: Struggles of a Native Canadian woman. A new edition was published in 1990 by Women's Press, Toronto. This incorporates additional material, including a foreword by Jeanette Armstrong, as well as a prologue and epilogue by Maracle. ${ }^{6}$ The 1990 edition is presented with an introductory chapter, 'Oka Peace Camp - September 9, 1990'. Here she emphasises that 'We all know that we must talk. Really talk - from a position of wholeness, completeness - about building a sustainable movement in the country ... The life of Bobbi Lee is about why we must talk. ${ }^{7}$

With regard to the history of production and publication, Bobbi Lee bears resemblance to Karukku in that there is the presence of Don Barret in its production, who acts as almost a mentor. Maracle dedicates 'both volumes' of her book to the memory of Don Barret. At the same time she expresses the discomfort she experienced in collaborating with him. She cites her own experience as an illustration of the fact that 'As-told-tos between whites and Natives rarely work.' Her verdict on the 1975 edition is summed up in these words: 'In the end, the voice that reached the paper was Don's, the information 
alone was mine'. (There is, in contrast, no hint of an overbearing presence in the 'support' given by Fr. Mark Stephen to Bama). Though Don Barrett was a leader who 'believed' in Maracle's 'potential' and tried 'to groom' her and encouraged her 'to get command of [her] voice' she could not cope with his 'centralist leadership'. ${ }^{8}$ Nor was she convinced that his ideology could pull the Native people out of the mess they were in. Therefore she 'decided to seek out that "lonely attic" in which writing, theory, story and life is imagined and put on paper'. ${ }^{9}$ In the epilogue to the 1990 edition of Bobbi Lee, Maracle states that through 'the long process of unravelling that began in 1975' 'missing pieces ... came alive' and 'Some of those memories are partially accounted for in I Am Woman'. ${ }^{10}$ Writing stories became an activity she indulged in to keep sane. She realised that all that tormented her 'had everything to do with racism and self-hate'. ${ }^{11}$ She testifies to the transformative power of story-telling when she states:

It took twenty-five years to twist me and only ten to unravel the twist. I still wrote for the demonstrations Native people held, but I began putting my need to write poetry and stories ahead of the political words that our people needed written. I became a woman through my words. ${ }^{12}$

\section{Two hegemonies and the Woman question}

Racism and casteism are beyond doubt dehumanising in their effects. Racism may be the offspring of colonialism while casteism owes its genesis to the caste system. Maracle draws attention to the fact that 'Racist ideology had defined womanhood for the Native woman as non-existent'. ${ }^{13}$ She says that in her activism she failed to recognise and acknowledge her gendered self. The assertion 'I am woman' came through an awakening to this reality. On Women's Day, 1978, she declared in a video presentation made for the occasion, that it was irrelevant to her that she was a woman and what mattered to her was the fact that she was Native. A gentle nudge to her conscience came from a well-wisher who had watched this presentation. He praised her understanding of the colonial process and added, 'couldn't you see that perhaps it was because you were Native and woman that your insight was powerful?' He also asked another penetrating question, 'Don't you think you could have taken responsibility for being a woman and inspired our sisters, just a little?' ${ }^{14}$ Some soul-searching and reflection led Maracle to realise that she was always conscious of convincing white colonial society that she was 'not like the rest of them ... an alcoholic ... a skid row bum ... a stupid Native'. ${ }^{15}$ She realised that racism had warped her sense of self. She examined the historical process - a whole set of dehumanising policies: before 1961 the Native people were considered 'wards of the government, children in the eyes of the law'. Rebellion against this attitude gave rise to remedial policies through Native self government and the Native land question. This being the case, 'The woman question still did not exist for us. 
Not then', says Maracle. ${ }^{16}$ She highlights the complicity of white women in the subjugation of Native women: even in the 'white women's movement' she observes, 'White women invite us to speak if the issue is racism or Native people in general. We are there to "teach", to "sensitize them", or serve them in some other way. We are not, as a matter of course invited as an integral part of "their" movement - the white women's movement. ${ }^{17}$

Bama states that Sangati (which means 'news') is all about what it means to be Dalit and woman. Drawing attention to the fact that mainstream society which discusses the 'position of women', takes no notice of Dalit women, she states: 'We have all come across news, broadcast widely and everywhere telling us of the position of women in our patriarchal society, and of the rights that have been plucked away from them. But news of women who have been trapped not only by patriarchy but also by caste-hatred is often side-lined, hidden, forgotten.' ${ }^{18}$ The tendency to 'side-line' Dalit women and matters pertaining to them is also addressed by Dalit writer Kumud Pawade. ${ }^{19}$ For example, at conferences of the women's movement in India, she has had to challenge the upper caste women's assumption that 'the entire woman caste is dalit' ${ }^{20}$

The urgent need to study and take affirmative action on the issues pertaining to Dalit women cannot be emphasised better than in the report in The Hindu about the Eighth National Conference of the All India Democratic Women's Association (AIDWA) held in Kolkata in November 2007 where a resolution was passed stating that the AIDWA would strongly take up the cause of Dalit women. $^{21}$

Both Sangati and I am woman are charged with the writers' urge to communicate the 'difference' of Native/Dalit women from white/upper caste women. Maracle makes a clear bid for highlighting the fact that the white women's movement and their feminist ideology exists beyond the pale of the indigenous woman's experience. Australian Aboriginal theorist Aileen Moreton-Robinson focuses on this issue in Talkin' up to the white woman: Indigenous women and feminism. In her critique of the liberal feminist argument she writes:

Because it centres white middle-class women as the normative position from which to judge the oppression, liberal feminism dehistoricises women and lacks an understanding of the different historical and material conditions that enable certain women to compete on the basis of merit. The invisibility of white race privilege and racial and class oppression is an outcome of giving primacy to gender oppression and sex difference. $^{22}$

She observes that, even when white feminists engage with a politics of difference, 'the effect of such theorizing is to make a politics of difference colour blind in terms of whiteness and power evasive in that all differences are rendered equally 
significant'. On the other hand women of colour, indigenous women and Afro-American women who theorise on difference 'do include within their respective positions the idea that there is some fixity to difference in power relations which places limits on inter-subjective relations' ${ }^{23}$ Moreton-Robinson also observes that though bell hooks 'sees feminism as being fundamentally racist, she believes it has something to offer Black women in America' ${ }^{24}$ To use the language of information technology, feminism may be viewed as software that is infected with racism and therefore this software will not work on Native systems (individual and collective). In Moreton-Robinson's view feminism has something to offer, but 'what is required is a redefinition of feminism'. ${ }^{25}$ This redefinition of feminism/feminism which is inclusive of Indigenous/Dalit women's experience, is one in which white race/upper caste privilege is interrogated.

\section{Transnational feminism and a world space for women}

The interesting parallels between the literary careers of Maracle and Bama, their identification with the women of their respective communities, their commitment to highlighting the difference of the Native/Dalit women from women of dominant society, and their celebration of difference, require for discussion a location that is not governed by temporal and spatial considerations. Bama and Maracle belong to two geographical extremities and yet there are so many interesting ways in which their work may be seen as intersecting. They belong to an imagined community.

The opportunity to present this paper at the Indigenous Biographies and Autobiographies Conference, held in Canberra, had for me a moment of truth when the objective of my presentation settled on me with a strong force and armed me with a strong sense of purpose. As a foreigner and one untrained in the use of maps to find locations, I realised quite suddenly that I could locate my 'position' on a map by looking for 'intersections'. The ways in which Sangati and I am woman intersect, gives each of these writers a 'position', a location and a shared space in the global arena. This venture, which draws from two texts and contexts, is a kind of mapping which is so significant at a time when Dalit people seek to internationalise their issues. Finding these intersections with Maracle's writing and her journey as a writer, creates a location, and a global one at that, not merely for Bama's Sangati, but for understanding the experience of Dalit women.

This concept of 'location', of creating a 'world space' for that which could be passed over as a regional issue, is theorised through 'transnational feminism', promoted by Caren Kaplan and Inderpal Grewal. In their view there is a need for women to 'work collaboratively in order to formulate transnational feminist alliances' ${ }^{26}$ Kaplan states that the transnational feminism they advocate should not be confused with Western feminists' ideas of 'a global sisterhood of women 
with shared values'. ${ }^{27}$ They argue that ' $[t]$ he claiming of a world space for women raises temporal questions as well as spatial considerations, questions of history as well as of place. ${ }^{28}$ In applying the theory of transnational feminism we are warned against 'constructing similarity through equalizations when material histories indicate otherwise'. ${ }^{29}$ Bearing this word of caution in mind, this paper turns the spotlight on intersections that function as sites of information flow: these intersections could be caused by either similarity or difference. There is therefore a 'politics of location' involved. Kaplan states that this practice should be viewed as 'affiliation' or 'coalition'. In her view 'a practice of affiliation, a politics of location identifies the grounds for historically specific differences and similarities between women in diverse and asymmetrical relations, creating alternative histories, identities, and possibilities for alliances' ${ }^{30}$ Maracle in her writing displays this consciousness of forging alliances with similarly displaced or marginalised peoples - 'Palestinians, Chileans, Filipinos, Eritreans, Ethiopians, El Salvadorans, Anti-apartheid activists and Black Canadian and American people who broadened [her] thinking and opened [her] eyes to the world of struggle and the joyous anticipation of new humanity that is being worked out in their countries'. ${ }^{31}$

Bama's transnationalism does not find expression in the text of Sangati. However, when I asked for her view on whether Dalit issues had to be internationalised she said:

Take Sri Lanka. Such a small country and the separate Tamil Eelam that they are asking for, because it is internationalised it is getting attention and it is going on. I'm not equating the issues, but just using it to explain. The problems of Dalits' issue is for thousands and thousands of years. The history of this caste system is for many years. For many years we were kept like that and without abolishing this caste system. India cannot become equal to any other country in this world though it has all resources - economic, nuclear and intellectual, etc. ${ }^{32}$

She referred to the response received by her book in France and other countries. The French translation of Sangati was published in 2002. She noted her interaction with a scholar engaged in a comparative study of her stories and those of Alice Walker. She was very appreciative and excited about the points of intersection.

The internationalisation of Bama's work has taken it beyond the regional level to the international arena. It is through book fairs like the one she went to in France and the transnational studies of researchers, that Bama has been included in the 'world of struggle' of which Maracle speaks.

In the critical parlance of Caren Kaplan and Inderpal Grewal, colonialism and casteism may be described as 'scattered hegemonies'. We are yet to examine, in 
the light of Bama and Maracle's writing, how patriarchy allies with colonialism and casteism in subjugating Native/Dalit women. Maracle's I am woman and Bama's Sangati, when drawn together by a comparative study, occupy a 'location'. In this location there are some sites that present an alternative history that is not dependent on temporal and spatial considerations.

\section{Love, sex and power}

'Isn't love a given?' is a question that Maracle raises in her justification of lesbian relationships. Her defence of lesbian relationships draws attention to the question of love, and she juxtaposes this against heterosexual relationships which are characterised by aggression and violence from the male partner. In many cases of heterosexual relationship the home is the site of rape. Lee links this issue to lesbianism to suggest that if brutal, loveless, heterosexual relationships are accepted, why not a love relationship between two women. She brings home the idea that relationships are based on love and not the question of power. Her analysis of the abusive behaviour of both Native and white men towards the Native women reveals that rape of Native women has its roots in racism. The white man, the Native man, the white woman and the Native woman are subjected to Lee's psychoanalytic scrutiny. White male abuse of the Native woman is pinned down to her being 'the object of the kind of sexual release of white males whose appetites are too gross for their own delicate women' ${ }^{33}$

In her view the Native man has a craving for white flesh and the brutality he inflicts on the Native woman is a result of frustration. In her study of rape she finds that fear in the woman excites the man. The Native woman, who subjects voluntarily to such brutality, reaches a point of self loathing which has its repercussions in the form of alcoholism and child abuse. It might be argued by some that rape in marriage is not exclusive to Native/coloured women/women from marginalised groups: it could very well be the case in the homes of white/upper caste women. Maracle's objective here is confined only to the 'why' of rape in the homes of Native people. Her analysis points to the frustration that is a result of ungratified attraction that Native men have towards white women. This kind of attraction of opposites can be seen in the white men's attraction to dark-skinned Native women. Describing the play of power in this eroticism, she says that they are 'frenzied by dark-skinned sensuality' and want for themselves 'the self-effacing surrender of dark women to white superiority'. ${ }^{34}$

In Bama's presentation of power relations, she does point out that Dalit women among whom she has lived are subject to sexual exploitation by upper caste men and are subject to brutal sex at the hands of their own husbands. However, Dalit women also employ strategies to cope with their situation. In this they show a marked difference from upper caste women whose torment is hushed within the walls of their homes. Bama states that the Dalit women of her 
community bring their domestic quarrels right onto the streets. Justifying their loud ways, she says that they work at home and outside the house and cope with almost no financial support from their husbands. Therefore, 'If he shows his strength of muscle, she reveals the sharpness of her tongue. Because she can't hit him back, she curses him roundly. ${ }^{35}$ This cursing is full of expletives. She seems to find a reason for the kind of language they use when she says, 'No matter what the quarrel is about, once they open their mouths, the same four-letter words will spill out. I sometimes think that because they have neither pleasure, nor fulfilment in their own sexual lives, they derive a sort of bitter comfort by using these terms of abuse which are actually names of their body parts. $^{36}$

\section{A patriarchal religion}

Religion is one of the forces that Bama identifies as being responsible for the subjugation of women. Bama's village is Dalit and Catholic. (It was the European missionaries who brought Catholicism to her village.) The festivals that they observe are Christian. In the midst of the excitement about the pageantry, about who is going to play Jesus and who will play Our Lady, the gender discrimination stands out glaringly. The women are not allowed to take any of the roles. They go to the ridiculous extent of men playing the roles of women. One of the women asks why a woman cannot play the part of Jesus. A conversation with Pecchi and Irulaayi who belong to another Dalit community, the chakkilis, brings her to realise that Dalits who have converted to Christianity are governed by Christian marriage laws in which marriage is binding for life. Irulaayi makes a statement on her people's position on the question of leaving one husband for another: 'it's quite common with us. It's only you Bible-people who can't do it. We are Hindus. But even amongst us, it's only the pallar and chakkili communities who can end one marriage and go and marry a second time. None of the other communities do it'. ${ }^{37}$ The woman who wants to separate has the opportunity to present her case before the village headman and she is free to separate and marry again. Bama's resentment of institutionalised Christianity finds expression in her narration of how even the Catholic priest did not stand by the young lovers who defied the sanctions of caste and desired to be united in marriage.

A section of I am woman is devoted to presenting the erosion of Native culture that was hastened by the coming of Roman Catholicism into their communities. The 'black robes' (Catholic priests) brought Europe and her ways with them. Maracle observes that they made for the colonies in a bid to escape Europe and she asks this incisive question: 'why do they have to bequeath the very things they escape to us?' She presents this question through the voices of the Native grandmothers who accept the imposition of European education on their children and grandchildren. They encourage their children and grandchildren to 'Master their language' for 'hidden within it is the way we are to live among them'. It 
is a decision that they make with resignation because to them it has become 'clear that they [the Europeans] will never go away'. ${ }^{38}$ It could also be viewed as a strategy for survival.

Maracle has not explicitly pointed out the patriarchal nature of Catholicism, but describes it in terms of a very masculine presence. One observes that it is the grandmothers who have engaged with Catholicism and contemplated the possibility of 'the coming together of ... histories' ${ }^{39}$ She acknowledges their subversion of colonial power with these words, 'I would not have had such thoughts if the grandmothers of this land had not battered themselves with this question [of mastering the colonisers' language], mused aloud in the presence of their granddaughters' ${ }^{40}$ The point of intersection that Bama has with Maracle with regard to religion is the feeling that the coming of the Christian missionaries into their community eroded their culture. Bama also points out that the Dalit Christians do not enjoy the privilege of reservation for jobs and other concessions that the government gives to other Dalits. She is also very sore about the hypocrisy and insincerity of the nuns and priests. She has expressed this strongly in Karukku, Sangati and in her interview with me.

\section{The ways of the grandmothers}

Interestingly Bama and Maracle foreground the presence of the grandmothers: they are repositories of the history of the community. They play an active role in the life of the community, stepping into areas of need. Time and again the narrator of I am woman recalls her grandmother's words of wisdom: the words of her grandmother help her learn about the history of her people. Maracle has to make a conscious effort to learn the ways of her grandmothers. Colonisation has eroded Native culture. Maracle states that she 'bent in the direction of European ideology' and 'hid for a long time from the teachings of the ancient ones'. She admits, 'When my sickened spirit needed to be healed though, I sought the teachings of my grandmothers'. ${ }^{41}$ Maracle quotes a Native belief which states, 'If you live right the grandmothers will take care of you'. ${ }^{42} \mathrm{~A}$ corollary of this is, 'if you live wrong they will forsake you. You will sicken and perhaps die'. ${ }^{43}$ This Native proverb operates in her narrative to emphasise the significance of Native women in shaping the history of the Native people. Woven into the narrative are Maracle's own joys and yearnings as a mother. Her narrative betrays her preoccupation with the education of her children, not in the European sense, but in terms of life skills and values. As a committed writer she is conscious of expressing the concerns of the women and children who have been a part of her life. Her reflections on the role of Native women in antiquity and for posterity are expressed in the poem 'Creation':

\section{I know nothing of great mysteries}


The grandmother of the narrator of Sangati is a vibrant presence. She is a highly respected member of the community because she has served the community as midwife. She has a story to say about the birth of each child in the community. In Bama's Sangati, the education of her granddaughter takes place when the two of them are engaged in their favourite activity: the granddaughter picks lice from the grandmother's hair and through her seemingly endless store of stories she imparts to her granddaughter the ways of their people. In one such moment of communion with her Paati (grandmother), the narrator chafes with indignation at the humiliation of Mariamma, on account of the false charges framed against her by a lustful upper caste landlord. She is unable to brook the fact that neither Mariamma, nor any other woman could speak up against the injustice.

Whether it is right or wrong, it is better for women not to open their mouths. You just try speaking out about what you believe is right. You'll only get kicked and beaten and trampled on for your pains. And it isn't just here that it happens, you know. It's the same throughout the world. Women are not given that kind of respect. ${ }^{45}$

This is what years of subjugation under patriarchy have taught Paati. The events she has witnessed in her life have led her to believe that '[i]f you are born into this world, its best that you are born a man'. ${ }^{46}$ Though there is a kind of resignation in these words, there are many episodes which show that it is the grandmother who takes initiative to do something for the welfare of her grandchildren and other women in the community. In the story of Mariamma, it is the narrator's mother and grandmother who take her to the doctor because she has not reached puberty. Medical attention solves the problem by establishing that Mariamma's anemic condition is the actual cause. The grandmother steps into the lives of the women of the community, in their very hour of need, whether it be a matter of child birth, ill-health or domestic violence. They inscribe in the narrator's consciousness the value that, rather than single-handedly fight or resist male domination or aggression, a more effective strategy is that of women being together and being there for each other. This aspect of community life is stronger among Bama's people. Maracle acknowledges that this aspect has disappeared from the lives of Native people. Expressing her yearning she says, 'I am a hungry woman. I hunger for my homeland, ailing and sick, that it is. 
Ka-Nata, "spirit of community." I hunger for an end to the robbery and hunger for the spirit of community to envelope my home again. ${ }^{47}$

\section{Native and Dalit women's souls and bodies}

Maracle draws on the experiences of her people to define the ways in which what happens to the body affects the soul. Native women often find that in their relationships with their husbands or lovers they are objects of lust. Maracle dwells at length on the question of love and of how dehumanising it is to be the object of lust. Having to cope with a loveless life, the earning of their daily bread and the raising of their children, leads to withdrawal. In her presentation of the sad story of Rusty, Maracle writes of how Rusty's spirit withdrew and 'jumped into the ever-present wine bottles that men and her good looks brought'. ${ }^{48}$ She reiterates in I am woman that her humanity, which was trampled on by the racism and sexism that she was subject to, was revived by the love she found in her second marriage. She brings her experience - past and present - to understanding and presenting the lives of Native women. She shows that Native women are viewed through the lens of racial prejudice and regarded as sub-human - 'the female of the species' ${ }^{49}$ This being the case '[they] are by definition, incapable of womanly love. It is aggressive sex that [they] get - a passionate body language but no spiritual affection' ${ }^{50}$ The result of such denial is an increased yearning, a vicious cycle of yearning and denial. Describing the despair in which they find themselves, she writes, 'Our life is lived out schizophrenically. Our community desires emancipation. The greater the desire, the more surely do we leap like lemmings into the abyss of alcoholism, violence and suicide. ${ }^{51}$

In Sangati, which is a collection of episodes from the life of her community, Bama presents the myths about peys (evil spirits) possessing people and she notes that in all the stories she has heard from her grandmother the spirits only seem to possess women. She is suggesting that what is taken to be possession by evil spirits is actually a manifestation of the psychological stresses that women of her community have to endure. At the same time, she shows that her people are full of song and dance. They have songs for every occasion, from birth to death and it is the women who sing these songs. There are the roraatu (lullaby), oppari (dirge) and also songs sung at a girl's coming of age. ${ }^{52}$ In an interview with me she described how the whole village stood by her when she lost her parents, one after the other in a matter of two days. In this excerpt she explained the necessity of song and dance even at the time of death:

MP: As a non-Dalit I don't understand how that happens? Why the dance?

Bama: Dance in the sense they have a particular song for that occasion and they sing and they dance, that says, 'Death is inevitable'. They don't 
cling on to anything actually. That detachment. You may not understand or accept. It is paradoxical. One thing is that they indulge in life and pleasure.

MP: At that time.

Bama: No, no in the culture. Indulge. That is part of Dalit culture and detachment that also is part of Dalit culture. See, if they want to make love, they make it to the full and enjoy it. And if there is some pain they indulge in it to the last drop of it.

MP: That purges it out.

Bama: And singing is part of their life. While working. During death also they sing. At the time of birth they sing. ${ }^{53}$

\section{Celebrating difference}

When it comes to celebrating themselves, there is a resonance between I am woman and Sangati. When Maracle writes, 'I want the standard for our judgement of our brilliance, our beauty and our passions, to be ourselves', her voice resonates with Bama's who appreciates the robust dark-skinned bodies of the women of her community. In one of the episodes in Sangati, Devi, a Dalit child, wonders if the dark coloured ragi kuzh (gruel) which is the staple food of her community of Dalit people, is the reason for their being 'born coal-black in colour, just like crows', and wonders if the fair skin of upper caste people is due to the rice and milk that they consume. Rendupalli, a woman from the Dalit community rises in defence to reply: 'Black is strongest and best, like a diamond. Just go to their [upper caste] streets and look about you. Yes, they might have light skins, but just take a close look at their faces. Their features are all crooked ... If they had our colour as well, not even a donkey would turn and look at them. ${ }^{54}$

Maracle's celebration of Native womanhood comes from her assertion 'I am woman'. She aptly describes her writing as 'channeled through the pen of a recently decolonized woman'. ${ }^{55}$ The awakening to self and life came only by getting rid of the colonial baggage and its attendant patriarchy. Her poem 'Fish-Wife' juxtaposes stereotypical images of the Native and white woman. One is 'loud, lean, raw', with 'no manners and no finesse ... but very much alive'. ${ }^{56}$ The stereotype of the white woman she sees on billboards is of a person for whom 'physical work is damning' ${ }^{57}$ In contrast Maracle's image of the Native woman is of a person 'for whom mobility, muscular movement, physical prowess are equal to the sensuous pleasure of being alive' ${ }^{58}$ 


\section{Native and Dalit men's subjugation}

There is no opportunity for Mariamma to establish the truth about the lewd conduct and advances made by the upper caste man towards her. In a bid to silence her, he claims that he was an eyewitness to her improper conduct with a young Dalit man. His allegations are accepted by the men in the Dalit community. In another instance the narrator asks her grandmother, why paraiya women do not go to the theatre to watch a movie. She is told that it is so because they want to avoid caste men. Even in the village, the women go out together to gather firewood and so on. They fear that they will be preyed upon. The Dalit men cannot confront the upper caste men in such cases because of their economic dependence on them as landlords. Bama attributes the domestic violence in Dalit homes to the same cause of suppressed manhood of the Dalit male; she writes:

Nowadays, when I reflect on how the men in our streets went about drinking and beating their wives, I wonder whether all that violence was because there was nowhere else for them to exert their male pride or to show off their authority. All that suppressed anger was vented when they came home and beat up their wives to a pulp. ${ }^{59}$

Maracle's writing about the erosion/corruption of the Native man's manhood is equally compelling. She ascribes the brutishness in Native men to the ill-effects of colonisation. She finds a kind of hierarchy in the present way of life where 'The dictates of patriarchy demand that beneath Native man, comes the female Native. The dictates of racism are thus that Native men are beneath white women and Native females are not fit to be referred to as women. ${ }^{60}$ Maracle expresses her resentment of Native men's practice of standing up when a white woman enters the room. It is a clear indication of the psychological conditioning about the place assigned to Native men. Colonisation has also conditioned them to behave 'like lesser white men of the brutish type'. ${ }^{61}$ In the traditional culture of Maracle's people, 'men responded to women' and the woman's 'choice was sacred'. However, with the erosion of 'traditions that kept us human', many indigenous women endure rape at the hands of drunken husbands. ${ }^{62}$

\section{The plight of the children}

Both narratives reveal that girl children in Native and Dalit communities witness a great deal of domestic violence. Maracle speaks explicitly of the abuse that the child suffers at the hands of a brutal father/the mother's partner. The story of Maikanni in Sangati is heart-wrenching and very powerful. Dalit men are often irresponsible and do not bring their wages home. Maikanni is the bread winner as her father has deserted the family. She works, sticking on labels in the matchbox factory. She represents the problem of child labour in India, which affects Dalits more than other communities. Maikanni narrates an incident of how she was lured by a man to pick firewood in a lonely part of the forest. But 
she is wise in gauging his intent and flees from the scene. The narrator wonders what life has made of Maikanni. 'If she was required to work far harder than her years demanded, she also behaved with a commonsense far beyond her years. ${ }^{63}$ The girl child in a Dalit community has a very brief childhood. The boys play freely. But the girl child is saddled with responsibilities - looking after her siblings, fetching water, firewood, helping with other domestic chores, and to top it all, many are like Maikanni, bringing home a wage.

The story of Maikanni finds a point of intersection with what Maracle's account of an episode concerning a L'ilwat child. As a volunteer parent on a school trip she notices that the European girls did not speak to the L'ilwat girl. On the return trip the little girl was standing while two European children occupied a three seater. The teacher was reduced to physically moving the European children and even then they gave her the bare minimum place to sit. The Dalit child Maikanni tells her aunts in the community of a caste-clash that takes place in the matchbox factory. Children from Maikanni's village are called paraiya and abusive names by children from a higher caste. It is strange that although their economic condition is the same as these Dalit children - they have also been driven to work in the matchbox factory - they have pride of caste. She holds her listeners in thrall as she narrates: 'If you had been there yesterday, you'd have seen a real fight going on. All the children from our streets refused to work; we even picked up our tiffin carriers and were ready to walk out. ${ }^{64}$ They resume work with pleas from the employer and assurance that he will not allow this to happen again.

\section{Narrating difference: effecting transformation}

Bama and Maracle's identification with the women of their communities is so deep that the phrase, 'the women in their bones' seemed an apt expression to bring into the title. It is due to this aspect of identification that Lakshmi Holmstrom, in the introduction to Sangati, describes this text as 'the autobiography of a community'. ${ }^{65}$ Moreover, the focus of Maracle and Bama is the difference of the women of their respective communities from women of mainstream society. This consciousness of difference has influenced their narrative style. To put it in Gopal Guru's terms, Bama and Lee Maracle's writings bear witness to the fact that Dalit/indigenous women 'talk differently'. Speaking to Manoj Nair about what the Cross Word award for Karukku meant to her, Bama says that what gave her 'most satisfaction' was the fact that the language of her people got recognition. The dialect that she employs in her writings was 'a language that was not recognized by the pundits of Literature, was not accepted by any literary circle in Tamilnadu, was not included in the norms of Tamil Literature'. But the success of Karukku 'forced the critics to accept the users of the dialect into their fold'. Bama says that she was proud of being 'instrumental in bringing about this change in Tamil Literature'. 
This aspect of 'talking differently' creates genres that are different from conventional mainstream productions. In their work on Vankar, Bhangi and Koli-Patel, women of the Bhal region of Gujarat, Franco Fernando and others have identified genre as a cultural production. They reiterate that the work of anthropologists and folklorists has helped to break genre's 'exclusive association with literary criticism' and regained its original meaning of class or type (Latin: genus, class). Gary Gosses, who worked with Chamula Indians in the 1970s, suggested that the organisation of genres reflects a world view. Franco Fernando et al. endorse this view: 'they [the genres] tell us something about the group's cultural grasp of the world. Genre thus becomes a social phenomenon rather than a formal one' ${ }^{66}$

In her essay 'Oratory: coming to theory', Lee Maracle states that in writing I am woman, she intended to write theory and that her quest took her through hundreds of books on capitalist theory, decolonisation, philosophy, Indigenous law, philosophy and culture. She puts the whole effort in perspective when she states:

My understanding of the process of colonization and decolonization of Native women is rooted in my theoretical perception of social reality, and it is tested in the crucible of human social practice. The stories and the poetry bring the reality home and allow the victims to devictimize their consciousness. For native women, and a good many white women, I Am Woman is empowering and transformative. ${ }^{67}$

Bama also emphasises this transformative, empowering effect of the stories of her people when she states that Sangati 'changed' her. ${ }^{68}$ 'What liberated you?' was a question that I posed to her in my interview. Her spontaneous response was 'Dalit culture'. The following excerpt brings home the transformation associated with the production of Sangati:

MP: Okay, I want to ask you, 'Where does your strength come from?' In Sangati you say: 'To bounce like a ball that has been hit became my deepest desire and not curl up and collapse because of the blow'. When did you arrive at this philosophy? When? How?

Bama: When I wrote Sangati. I wrote about different women.

MP: So it was at that point. Not Karukku.

Bama: No, not Karukku.

MP: Would you say that you became more vociferous, more confident after Karukku?

Bama: Not after Karukku. After Sangati.

MP: After Sangati? 
Bama: Not after, while writing Sangati. See at the end of Karukku I have written, 'Like a bird whose wings have been broken, I am now' ${ }^{69}$ That was the condition when I wrote Karukku. I wanted to fly freely but my feathers were cut. But while writing Sangati, the women who were against this oppressive system, that was in me. ${ }^{70}$

The word that captures the spirit of Bama and Maracle's story-telling is 'transformation'. Kay Schaffer and Sidonie Smith's study titled Human rights and narrated lives: The ethics of recognition, enhanced my understanding of the transformative power that operates in and through the texts Sangati and I am woman. Their study ranges from the stories of 'comfort women' in Japan to 'the stolen children' in Australia and the stories of Tiananmen Square in China. The authors of Human rights endeavour to present story telling's link with human rights campaigns: their study shows that the narratives undergo transformation and gain greater efficacy through their connection with the human rights discourses, platforms and campaigns. The reception of their stories and the wide audience they sometimes gain also enable this process of transformation. With avenues for telling their stories and participation, especially in cross-cultural exchanges and exposure to human rights discourse, comes transformation. 'These confident narrators reveal astute political awareness, utilizing a language of human rights' ${ }^{71}$ It is the language of human rights that informs the narratives Sangati and I am woman. Tracing the journeys of these two women, Bama and Lee Maracle, reveals that their coming into contact with human rights activists was responsible for the recording of their life stories - Karukku and Bobbi Lee. The progress of each of these women from their first publication to presenting through autobiographical fiction a compelling case for the recognition of the 'difference' of the women of their respective communities from women of mainstream cultures, bears witness to the forces of transformation at work. They have discovered that committed writing is their vocation. The revolutionary intent in writing Sangati is expressed by Bama in her acknowledgments: 'Sangati grew out of the hope that the Dalit women who read it will rise up with fervour and walk towards victory as they begin their struggle as pioneers of a new society. $^{, 72}$ Maracle's writing is also governed by her consciousness of being in 'the world of struggle' that works towards 'a new humanity'. ${ }^{73}$ She articulates the journey that she made from the frontlines of activism to the lonely attic of a writer and her conviction that writing was what she was meant for. Her writing is replete with the discourse of human rights.

There is however a marked difference between the register that each of these writers employ. In Bama's stories one does not encounter the terms feminism, casteism or patriarchy: she uses the words caste and patriarchy only in the acknowledgements. However, the narrative is unmistakably informed by the zeal of a crusader for the rights of Dalit women and an assertion of their 
uniqueness and their humanity. Maracle's writing on the other hand is more academic.

\section{Conclusion}

\section{Transnational destinations: moving voices, finding spaces}

The efficacy of transnational feminism became tangible when Bama explained to me, as shown in the excerpt below, the impact of a researcher's cross-cultural study of Bama's short stories and those of Alice Walker:

MP: You were talking with great passion about Alice Walker.

Bama: Yeah because Alice Walker ... There is a lady in Stella Maris College, there is an English lecturer, Agnes, she has done this comparative study. Her thesis was titled 'Celebrating Life' and I just love it because for me also life is to be celebrated and for Alice Walker too. Most of her stories are from the Christian background, about how those people were treated within the Church by the whites. In spite of all those things they celebrate life. Some such similarity when I find, I'm interested to read. Even poetry. That is the thing. We may face a hundred and one atrocities and things like that. But still we rise above these things. ${ }^{74}$

This aspect of 'rising above' is what characterises Maracle's and Bama's work. This study is presented with the hope that the voices of these marginalised women who have already taken wing, will soar to many more transnational destinations by means of which more locations for dialogue and exchange of information will open up.

\section{References}

Bama 1992, Karukku, IDEAS, Madurai. 1994, Sangati, IDEAS, Madurai.

2000, Karukku, Trans. Lakshmi Holmstrom, Macmillan, Chennai.

2005, Sangati, Trans. Lakshmi Holmstrom, Oxford University Press, Chennai.

Bataille, Gretchen and Kathleen Mullen Sands 1984, American Indian women telling their lives, University of Nebraska Press, Lincoln.

Chattopadhyay, Suhrid Sankar, 'AIDWA to take up the cause of Dalit Women', The Hindu, 4 November 2007, accessed at <http://www.hindu.com/2007/11/04/stories/2007110456401500.htm>

Franco, Fernando, Jyotsna Macwan and Suguna Ramanathan (eds) 2000, The silken swing: The cultural universe of Dalit women, STREE, Calcutta. 
Grewal, Inderpal and Caren Kaplan 1994, Scattered hegemonies: Postmodernity and transnational feminist practices, University of Minnesota Press, Minneapolis.

Guru, Gopal 'Dalit Women Talk Differently', Economic and Political Weekly: 2548-2550.

Holmstrom, Lakshmi 2005, 'Introduction', in Sangati, Bama, Trans. Lakshmi Holmstrom, Oxford University Press, Chennai: xi-xxiii.

Maracle, Lee 1975, Bobbi Lee: Indian rebel: struggles of a Native Canadian woman, Liberation Support Movement Press, Richmond, B.C.

— 1988, I am woman, Write-on Press, North Vancouver, B.C.

— 1990, Bobbi Lee: Indian rebel, revised edn, Women's Press, Toronto.

— 1994, 'Oratory: coming to theory', Essays on Canadian Writing 54, Winter: 7.

Moreton-Robinson, Aileen 2000, Talkin' up to the white woman: Aboriginal women and feminism, Unversity of Queensland Press, St Lucia, Queensland.

Rege, Sharmila 2006, Writing caste/writing gender: Reading Dalit women's testimonios, Zubaan, New Delhi.

Schaffer, Kay and Sidonie Smith 2004, Human rights and narrated lives: The ethics of recognition, Palgrave Macmillan, New York.

Warley, Linda 1996, 'Reviewing past and future: postcolonial Canadian autobiography and Lee Maracle's Bobbi Lee, Indian rebel', Essays on Canadian Writing, 60, Winter: 59.

\section{Interviews}

Interview with Father Mark Stephen, conducted by the author, 9 and 10 September 2006.

Interview with Bama, conducted by the author, 15 August 2006.

Interview with Bama, conducted by Manoj Nair, 'Recognition of the language of my people is the biggest award I can win', 26 April 2001, accessed at: <http://www.ambedkar.org/entertainment/RecognitionFor.htm>

\section{ENDNOTES}

\footnotetext{
${ }^{1}$ Cited in Bataille and Sands 1984: vi.

2 Bama 1992, 1994; Maracle 1988, 1975.

3 Bama 2000: xiv.

${ }^{4}$ Interview with Father Mark Stephen, conducted by the author, 9 and 10 September 2006.

${ }^{5}$ Interview with Father Mark Stephen, conducted by the author, 9 and 10 September 2006.

6 Warley 1996.

7 Maracle 1990: 11.
} 
Indigenous Biography and Autobiography

8 Maracle 1990: 19.

9 Maracle 1990: 20.

10 Maracle 1990: 201.

11 Maracle 1990: 229.

12 Maracle 1990: 230.

13 Maracle 1988: 16.

14 Maracle 1988: 17.

15 Maracle 1988: 16.

16 Maracle 1988: 17.

17 Maracle 1988: 20-21.

18 Interview with Bana, conducted by the author, 15 August 2006.

19 Rege 2006 presents excerpts in translation.

20 Rege 2006: 235.

${ }^{21}$ Chattopadhyay, The Hindu, 4 November 2007.

22 Moreton-Robinson 2000: 35-36.

23 Moreton-Robinson 2000: 63.

24 Moreton-Robinson 2000: 50.

25 Moreton-Robinson 2000: 50.

26 Grewal and Kaplan 1994: 1.

27 Grewal and Kaplan 1994: 137.

${ }^{28}$ Grewal and Kaplan 1994: 137.

${ }^{29}$ Grewal and Kaplan 1994: 139.

30 Grewal and Kaplan 1994: 139.

31 Maracle 1988: iv.

32 Interview with Bama, conducted by the author, 15 August 2006.

33 Maracle 1988: 18.

34 Maracle 1988: 61.

35 Bama 2005: 67.

36 Bama 2005: 68.

37 Bama 2005: 92.

38 Maracle 1988: 85.

39 Maracle 1988: 86.

40 Maracle 1988: 86.

41 Maracle 1988: 43.

42 Maracle 1988: 5.

43 Maracle 1988: 5.

44 Maracle 1988: 8.

45 Bama 2005: 29.

46 Bama 2005: 6.

47 Maracle 1988: 155.

48 Maracle 1988: 59.

49 Maracle 1988: 24.

50 Maracle 1988: 77.

51 Maracle 1988: 24.

52 Holmstrom 2000: xx.

53 Interview with Bama, conducted by the author, 15 August 2006.

54 Bama 2005: 114.

55 Maracle 1988: $\mathrm{x}$.

56 Maracle 1988: 18. 
57 Maracle 1988: 19.

58 Maracle 1988: 19.

59 Bama 2005: 65.

60 Maracle 1988: 20.

61 Maracle 1988: 29.

62 Maracle 1988: 29.

63 Maracle 1988: 75.

${ }^{64}$ Bama 2005: 74.

65 Holmstrom 2005: xv.

${ }^{66}$ Fernando et al 2000: 132.

67 Maracle 1988: para 16.

68 Bama 2005: viii.

69 This part of her speech coincides with the raucous, jubilant cawing of crows returning to their nests. There is also a shrill sound, almost like a whistle from an unidentified creature in the greenery around.

${ }^{70}$ Interview with Bama, conducted by the author, 15 August 2006.

71 Schaffer and Smith 2004: 113.

72 Maracle 1988: ix.

73 Maracle 1988: iv.

${ }^{74}$ Interview with Bama, conducted by the author, 15 August 2006. 